\title{
IMPLEMENTASI WEB SERVICE PADA INTEGRASI DATA AKADEMIK DENGAN REPLIKA PANGKALAN DATA DIKTI
}

\author{
Rifki Indra Perwira, Budi Santosa \\ Teknik Informatika, Universitas Pembangunan Nasional "Veteran" Yogyakarta \\ Tambakbayan 2 Babarsari, Yogyakarta \\ e-mail : rifki@upnyk.ac.id ; dissan@gmail.com
}

\begin{abstract}
The process of academic data reporting periodically to the Ministry of Research, Technology and Higher Education conducted twice each semester. Reporting is done at the beginning of the study and at the end of the study. Academic data which are many and varied makes an obstacle to be sent through the mechanism of technological systems. Each college should follow the system that created the Ministry of Research, Technology and Higher Education (DIKTI). To parse the existing problems, this study makes a bridge intermediaries who facilitate the process of sending data from the relevant authorities to the Ministry of Research, Technology and Higher Education (DIKTI). The data transmission process to go through several mechanisms such as the integration of all academic data in one database, mapping process, insert, update, delete process, and the last is the synchronization.

This study utilizes web services technology has the advantage that it can work multiple operating system platforms. Module web service that is implemented consisting of insert, update and delete which is a replication of the previous development so that reporting data can still be done though different systems.

The results of this study in the form of a web service tools which consists of three main modules that can accommodate the needs of academic data reporting to the Ministry of Research, Technology and Higher Education which has been running. These tools have been used in the last two years for reporting purposes.
\end{abstract}

Keywords : web service, computer based information system, academic

\section{Abstrak}

Proses pelaporan data akademik secara berkala kepada DIKTI dilakukan dua kali setiap semester. Pelaporan dilakukan di awal semester dan di akhir semester. Data akademik yang sangat banyak dan bervariasi menjadikan sebuah kendala untuk dapat dikirim melalui mekanisme sistem teknologi. Setiap perguruan tinggi harus mengikuti sistem yang dibuat DIKTI. Untuk mengurai permasalahan yang ada, penelitian ini membuat jembatan perantara yang mempermudah proses pengiriman data dari instansi terkait ke DIKTI. Proses pengiriman data tersebut harus melalui beberapa mekanisme seperti integrasi semua data akademik dalam satu database, proses mapping, proses insert, update, delete, dan yang terakhir adalah sinkronisasi.

Penelitian ini memanfaatkan teknologi web service yang memiliki keunggulan dapat bekerja multi platfom sistem operasi. Modul web service yang diimplementasikan terdiri atas insert, update dan delete yang merupakan pengembangan replika sebelumnya sehingga pelaporan data tetap dapat dilakukan meskipun berbeda sistem.

Hasil dari penelitian ini berupa sebuah tools web service yang terdiri tiga modul utama yang dapat mengakomodir kebutuhan-kebutuhan pelaporan data akademik ke DIKTI yang sudah berjalan. Tools ini telah digunakan dalam dua tahun terakhir untuk keperluan pelaporan.

Kata kunci : web service, sistem informasi berbasis computer, akademik

\section{PENDAHULUAN}

Latar Belakang

Dalam ilmu komputer dan teknologi informasi terdapat istilah integrasi data, dan integrasi sistem. Integrasi data merupakan suatu proses menggabungkan atau menyatukan data yang berasal dari sumber yang berbeda dalam rangka mendukung manajemen informasi dan 
mendukung pengguna untuk melihat kesatuan data. Data yang digabungkan merupakan data dari berbagai sumber database yang berbeda ke dalam sebuah penyimpanan seperti gudang data (data warehouse).

Syarat integrasi data dapat dipenuhi dengan berbagai cara seperti konsisten dalam penamaan variabel, konsisten dalam ukuran variabel, konsisten dalam struktur pengkodean dan konsisten dalam atribut fisik dari data. Masalah-masalah yang ada pada integrasi data yaitu heterogenitas data, otonomi sumber data, kebenaran dan kinerja query/permintaan sedangkan integrasi sistem merupakan suatu konsep sistem yang dapat saling berhubungan satu dengan yang lain dengan berbagai cara yang sesuai dengan keperluan, hal ini sangat bermanfaat bila suatu data dalam file suatu sistem diperlukan juga oleh sistem yang lainnya atau output suatu sistem menjadi Input sistem lainnya. Keuntungan dari integrasi sistem ini adalah membaiknya suatu arus informasi dalam sebuah organisasi. Suatu pelaporan biasanya memang memerlukan waktu, namun demikian akan semakin banyak informasi yang relevan dalam kegiatan manajerial yang dapat diperoleh bila diperlukan.

Penelitian ini dimaksudkan untuk menerapkan konsep tiga modul utama yang telah dibuat yaitu insert, update dan delete sebagai solusi dalam pengembangan integrasi data Akademik. Penelitian ini difokuskan pada mendukung pelaporan data akademik kepada DIKTI melalui mekanisme pengiriman data yang memanfaatkan modul utama insert, update dan delete.

Proses yang cukup berat adalah penyatuan database semua data akademik menjadi satu kesatuan container yang akan dimappingkan setiap variable yang digunakan agar data-data akademik dapat masuk dalam DIKTI. Dengan adanya modul insert, update dan delete maka proses pelaporan ini dapat terlaksana.

\section{Perumusan Masalah}

Berdasarkan uraian latar belakang diatas, maka rumusan masalahnya sebagai berikut:

1. Bagaimana implementasi integrasi data akademik dengan replika pangkalan data DIKTI di UPN "Veteran" Yogyakarta?

Tujuan

Penelitian ini bertujuan untuk:

1. Mengimplementasikan web service integrasi data CBIS akademik dengan replika pangkalan data DIKTI di UPN "Veteran" Yogyakarta yang dapat digunakan sebagai sarana pelaporan data universitas.

Manfaat

Adapun manfaat yang diperoleh sebagai berikut

1. Memudahkan operator dalam menggabungkan data-data akademik yang akan dilaporkan.

2. Memudahkan Universitas dalam pelaporan data akademik ke DIKTI.

3. Dengan format XML yang telah menjadi salah satu standar pertukaran data, memungkinkan universitas melakukan pertukaran data dengan pihak lain dengan berbagai platform dengan tingkat keamanan yang baik.

\section{Tinjauan Pustaka}

Penelitian terdahulu pernah dilakukan oleh Santosa \& Perwira (2016) dengan topik Pengembangan Integrasi Data CBIS Akademik Dengan Replika Pangkalan Data DIKTI UPN "Veteran" Yogyakarta Menggunakan Web Service. Penelitian saat itu sebagai model siklus pengembangan integrasi data CBIS yang menghasilkan tiga modul, yaitu modul insert, modul update dan modul delete sedangkan penelitian ini membahasa tahap implementasinya.

Penelitian lain oleh Sutanta \& Mustofa (2014) dengan topik pengembangan web services untuk integrasi inter sistem e-government di pemerintah kabupaten bantul merupakan hasil kajian pustaka yang bertujuan untuk mengungkap masalah sebuah strategi pengembangan web service untuk integrasi inter sistem e-gov dengan menggunakan studi kasus pada pemerintah Kabupaten Bantul, Yogyakarta. Metodologi yang dilakukan adalah dimulai dengan mengkaji konsep pengembangan e- Gov, kondisi aktual implementasi e-Gov di Pemkab Bantul, dan selanjutnya disampaikan usulan alternatif strategi yang bisa diterapkan dalam pengembangan web service untuk peningkatan e-gov melalui integrasi inter sistem dan website yang ada. 
Penelitian lain yang dilakukan oleh Hidayat \& Ashari (2013) tentang Penerapan teknologi web services untuk intergrasi layanan puskesmas dan rumah sakit ini mencoba membuat sebuah Jaringan terintegrasi baik di dalam sektor kesehatan (antar program dan antar jenjang), dan di luar sektor kesehatan, yaitu dengan sistem jaringan informasi rumah sakit pemberi rujukan maupun rumah sakit rujukan. Rancangan untuk arsitektur aplikasi yang akan dibangun dengan menggunakan Web Services ini mempunyai dua akses terdapat database pada masing-masing rumah sakit. Akses yang ada adalah send dan request, komunikasi yang terjadi adalah dua arah dimana pada sisi konsumen dapat melakukan permintaan-permintaan dengan paramater tertentu dan melakukan pengiriman-pengiriman data dengan paramater tertentu dengan melalui Web Services. Hasil dari implementasi teknologi web service untuk aplikasi integrasi layanan puskesmas dan rumah sakit, yang diperoleh dengan melakukan pengujian pada masing-masing service yang tersedia dan pengujian pada aplikasi.

Dalam artikel ilmiah yang ditulis oleh Hartono et al. pada tahun 2013 yang berjudul "Aplikasi Reservasi Tiket Bus pada Handphone Android menggunakan Web service" (Studi Kasus: PO. Rosalia Indah). Penyajian informasi ketersediaan tiket yang masih manual menjadi salah satu permasalahan yang dialami oleh jasa travel karena calon penumpang harus datang ke agen untuk mengetahui ketersediaan tiket. Berdasarkan permasalahan tersebut, maka dibutuhkan sebuah layanan yang mampu mendukung sebuah aplikasi client. Web service adalah layanan yang dirasa mampu mengatasi permasalahan tersebut. Web service yang berbasiskan XML sangat memungkinkan untuk diimplementasikan sehingga menjanjikan banyak kemudahan dan perbaikan dalam $m$ endukung integrasi berbagai platform system dan aplikasi, baik melalui insfrastruktur Intranet maupun Internet/Eksternet. Sistem reservasi tiket online yang dikembangkan dapat diakses melalui perangkat mobile memudahkan calon penumpang dalam mendapatkan informasi dan melakukan proses pemesaan tiket.

Yazdi pada tahun 2012 juga meneliti tentang web services dengan judul implementasi web services pada sistem pelayanan perijinan terpadu satu atap di pemerintahan kota palu. Metode yang digunakan dalam menyelesaikan masalah ini adalah metode siklus hidup pengembangan sistem informasi (Life Circle System Development Methodology) dengan pemodelan sistem meliputi perancangan logic sistem aplikasi, arsitektur sistem, dan perancangan visual modelling. Perancangan visual modelling mencakup use-case diagrams, class diagrams, sequence diagrams, collaboration diagrams, dan deployment diagrams. Paper ini membahas tentang penerapan teknologi web service untuk melakukan integrasi sistem informasi pelayanan perijinan terpadu satu atap dari bebrapa sistem informasi perijinan yang ada dengan platform yang berbeda.

Dalam jurnal penelitian yang dilakukan oleh Marthasari et al. (2010). Penelitian ini mengimplementasikan web service untuk mendukung interoperabilitas pada aplikasi ecommerce, dimana fleksibilitas sistem e-commerce yang masih dihalangi oleh persoalan interoperabilitas antar perangkat. Dengan memanfaatkan Web service memungkinkan perangkat yang berbeda platform dapat saling berkomunikasi yaitu platform web, desktop, dan HP. Dalam penelitian ini dihasilkan aplikasi e-commerce berbasis web service dengan studi kasus disebuah toko buku online. Aplikasi e-commerce ini dapat diakses melalui website, desktop.

\section{LANDASAN TEORI}

Arsitektur Web Service

Arsitktur Web Services dikutip dari Chen et al dapat dilihat pada Gambar 1.1. 


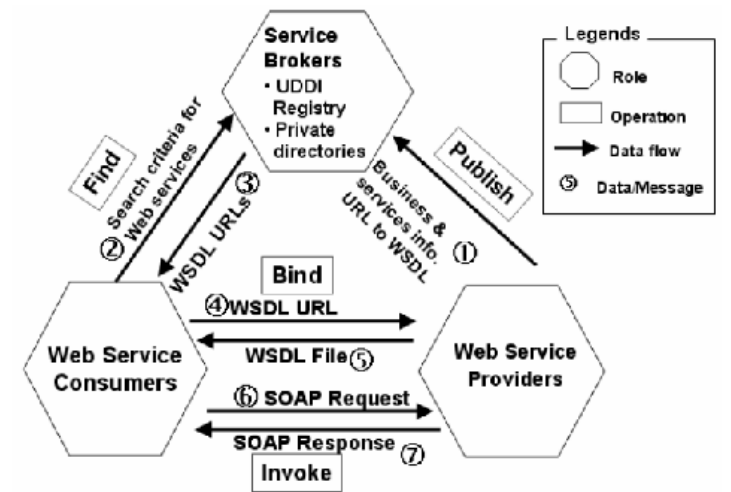

Gambar 2.1. Arsitektur Web Service (Chen et al, 2003)

Ada tiga besar peran dalam arsitektur web Service:

1. Penyedia layanan / Service Provider

Service provider adalah penyedia layanan web. Penyedia layanan mengimplementasikan layanan dan membuatnya tersedia di Internet.

2. Layanan Pemohon / Service Request

Ini adalah konsumen dari web Service. Peminta layanan yang mencari dan menemukan layanan yang dibutuhkan serta menggunakan layanan tersebut.

3. Layanan registri / Service Registry

Berfungsi sebagai lokasi central yang mendeskripsikan semua layanan/service yang telah di-register.

\section{Web Service}

Web service (Utama, 2010) adalah suatu sistem perangkat lunak yang dirancang untuk mendukung interoperabilitas dan interaksi antar sistem pada suatu jaringan. Web service digunakan sebagai suatu fasilitas yang disediakan oleh suatu web site untuk menyediakan layanan (dalam bentuk informasi) kepada sistem lain, sehingga sistem lain dapat berinteraksi dengan sistem tersebut melalui layanan-layanan (service) yang disediakan oleh suatu sistem yang menyediakan web service. Web service juga diartikan sebagai sebuah antar muka yang menggambarkan sekumpulan operasi-operasi yang dapat diakses melalui jaringan dalam bentuk XML (Kreger, 2001).

Web service memiliki empat lapisan dasar, yaitu

\begin{tabular}{|c|}
\hline $\begin{array}{c}\text { Service Publication and Discovery } \\
\text { (UDDI) }\end{array}$ \\
\hline Service Description (WSDL) \\
\hline XML Based Messaging \\
(SOAP)
\end{tabular}

\section{Gambar 2.2. Lapisan Dasar Web Service (Deviana, 2011)}

Lapisan dasar pada Gambar diatas merupakan blok bangunan web service yang mana menyediakan fasilitas komunikasi jarak jauh antara dua aplikasi yang merupakan layer arsitektur web service.

a. Layer 1 : protokol internet standar yang digunakan sebagai sarana transportasi adalah HTTP dan TCP/IP.

b. Layer 2 : Simple Object Access Protocol (SOAP) berbasiskan XML dan digunakan untuk pertukaran informasi antar sekelompok layanan. 
c. Layer 3 : Web service Definition Language (WSDL) digunakan untuk mendiskripsikan attribute layanan.

d. Layer 4 : Universal Description Discovery and Integration, yang mana merupakan direktori pusat untuk deskripsi layanan.

\section{Keuntungan Web Service}

Menurut Scoot (2003), beberapa keuntungan menggunakan web service adalah

1. Kerjasama yang baik di mana sebagai service jarak jauh sudah dapat digunakan oleh client dengan platform yang berbeda.

2. Model Hubungan antarmuka yang kuat dimaksudkan bahwa tipe data yang dikirim ke dan diterima dari Service jarak jauh tidak ambigu maksudnya model data yang didefinisikan oleh Service jarak jauh cocok dengan model data yang didefinisikan oleh mayoritas bahasa pemrograman yang telah ditetapkan.

3. Kemampuan standar Internet yang sudah ada dimaksudkan bahwa solusi yang sudah tersedia di dalam standar internet yang banyak dipakai dapat memakai tool set yang ada dan bisa menghasilkan produk dari teknologi tersebut.

4. Dukungan kepada semua infrastruktur komponen terdistribusi

\section{CBIS Akademik UPN Veteran Yogyakarta}

CBIS adalah singkatan dari computer based information system yaitu Sistem Informasi yang menggunakan komputer (berbasis computer) dan teknologi komunikasi untuk melakukan tugas-tugas yang diinginkan (sebagai alat bantu untuk pengambilan keputusan). Di UPN "Veteran" Yogyakarta, CBIS menjadi sebuah sistem informasi yang penting dalam pengelolaan akademik, baik itu input KRS, jadual, posting nilai, riwayat pembayaran, IPK sampai pengumuman seputar akademik. Sejarah CBIS sudah dipakai sejak tahun 2003. CBIS mengalami perbaikan secara berkala dari tahun ke tahun untuk mengakomodasi masukanmasukan atau permasalahan yang masih muncul.

CBIS saat ini ada enam yaitu :

a. http://ftm.upnyk.ac.id untuk Fakultas Teknik Mineral

b. http://fti.upnyk.ac.id untuk Fakultas Teknik Industri

c. http://fti2.upnyk.ac.id untuk Prodi D3 Kimia

d. http://fe.upnyk.ac.id untuk Fakultas Ekonomi dan Bisnis

e. http://fisip.upnyk.ac.id untuk Fakultas ISIPOL

f. http://fp.upnyk.ac.id untuk Fakultas Pertanian

Seiring dengan kebijakan-kebijakan baru dari Kementrian Riset, Teknologi dan Pendidikan Tinggi tentang pelaporan hasil pembelajaran dari instansi ke DIKTI, mengharuskan instansi mengirim data akademik ke DIKTI melalui mekanisme web service atau feeder. Penelitian ini akan membahas "jembatan" pelaporan antara instansi kepada DIKTI melalui mekanisme integrasi data CBIS yang menggunakan teknologi web service.

\section{METODE PENELITIAN}

Metodologi yang akan digunakan pada penelitian ini antara lain ; Studi Literatur dan SDLC (System Development Life Cycle) yang meliputi tahap Analysis, Design, Implementation, Testing dan Maintenance (Pressman, 2010). Metodologi ini dikenal dengan nama modified waterfall model yang tersaji pada Gambar 3.1. Metodologi ini dirinci sebagai berikut :

1. Studi Literatur

Tahap ini merupakan tahap pengumpulan informasi dan literatur yang diperlukan untuk pembuatan sistem. Adapun informasi dan literatur yang dipergunakan diantaranya tentang Sistem Informasi berbasis web yang berkaitan dengan promosi dan otomasi perkantoran.

2. Analisis dan perancangan

Pada tahap ini dilakukan analisis serta desain yang diperlukan dalam membuat sistem, diantaranya akuisisi pengetahuan, representasi pengetahuan, mekanisme inferensi, perancangan DFD, perancangan basisdata dan perancangan user interface.

3. Implementasi

Pada tahap ini, rancangan sistem yang telah dibuat akan diimplementasikan menggunakan php dan MySQL serta program pendukung dari DIKTI.

4. Uji coba dan evaluasi 
Pada tahap ini, akan dilakukan uji coba dan evaluasi terhadap sistem serta akan dilakukan perbaikan-perbaikan yang diperlukan.

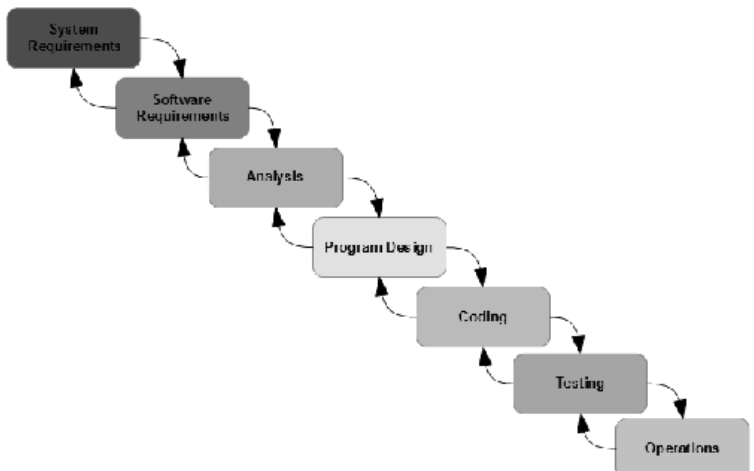

Gambar 3.1. Modified waterfall model (Pressman, 2010)

\section{Alur Data Awal}

Proses pelaporan data akademik membutuhkan tahapan yang panjang. Tahapan tersebut dapat dilihat pada Gambar 3.2.
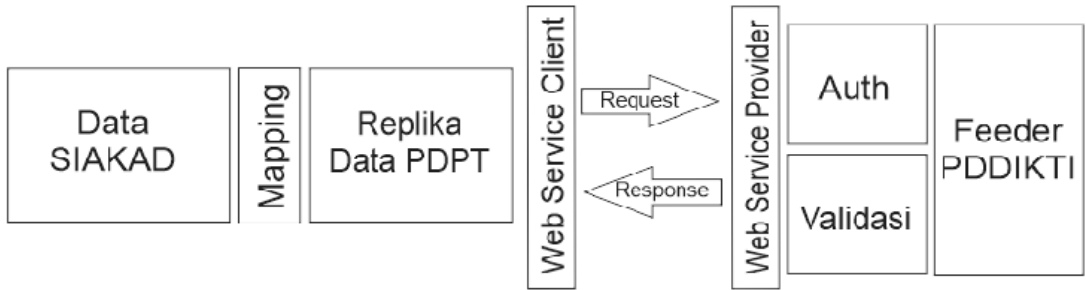

Gambar 3.2. Tahapan Pelaporan Data

Tahapan-tahapan tersebut adalah

1. Data SIAKAD : data mentah yang berasal dari masing-masing CBIS dalam satu container.

2. Mapping : proses mapping data atau penyesuaian data mentah dengan replika data PDDIKTI (PDPT).

3. Web Service : tahapan ini melakukan insert, update, detete data-data yang telah digabung sebelumnya untuk dapat dikirim ke aplikasi feeder.

4. Auth/Validasi : digunakan untuk mendapatkan keamanan (get token). Token diperoleh dari username password yang diberikan oleh operator DIKTI sedangkan validasi difungsikan sebagai sesi penilaian validitas sebuah data.

5. Feeder : setelah data dinyatakan valid, maka kemudian dikirim ke aplikasi feeder DIKTI yang merupakan lokalnya http://forlap.dikti.go.id

\section{HASIL PENELTIAN DAN PEMBAHASAN}

Langkah-langkah berikut ini adalah implementasi web service ini mulai dari data akademik awal sampai sinkronisasi pada feeder :

1. Untuk mempermudah akses database maka dilakukan penggabungan dari 6 bagian database yang ada di CBIS ke dalam 1 database container. Adanya perbedaan struktur database antara milik UPN dengan DIKTI mengharuskan melakukan proses mapping terlebih dahulu sebelum dimasukkan pada database feeder. Database mapping (tabel mapping) tersebut strukturnya mirip dengan database feeder PDDIKTI. Database tersebut sebagai dasar mapping antara database feeder PDDIKTi dengan database CBIS. Daftar tabel feeder PDDIKTI dapat dilihat pada Tabel 4.1 . 
Tabel 4.1. Tabel Mapping Database CBIS dengan Feeder

\begin{tabular}{|c|c|c|c|c|c|}
\hline Nama Field & type & keterangan & Mapping & Table & Nama field \\
\hline id_reg_pd & uuid & $\begin{array}{l}\text { Primary Key, } \\
\text { kosongkan ketika } \\
\text { mode Tambah }\end{array}$ & & & \\
\hline id_sms & uuid & $\begin{array}{l}\text { ID SMS (Satuan } \\
\text { Manajemen } \\
\text { Sumberdaya). } \\
\text { Web Service: } \\
\text { GetRecordset:sms }\end{array}$ & & mahasiswa & id_jur \\
\hline id_pd & uuid & $\begin{array}{l}\text { ID_PD } \\
\text { Mahasiswa. Web } \\
\text { Service: } \\
\text { GetRecordset:mah } \\
\text { asiswa }\end{array}$ & & & \\
\hline id_sp & uuid & $\begin{array}{l}\text { ID Perguruan } \\
\text { Tinggi. Web } \\
\text { Service: } \\
\text { GetRecordset:satu } \\
\text { an_pendidikan }\end{array}$ & & & \\
\hline id_jns_daftar & numeric $(2,0)$ & $\begin{array}{l}\text { Web Service: } \\
\text { GetRecordset:jeni } \\
\text { s_pendaftaran }\end{array}$ & & mahasiswa & jalur_msk \\
\hline nipd & $\begin{array}{l}\text { character } \\
\text { varying(24) }\end{array}$ & $\begin{array}{l}\text { NIM/NRP } \\
\text { Mahasiswa }\end{array}$ & & mahasiswa & no_mhs \\
\hline tgl_masuk_sp & date & yyyy-mm-dd & & mahasiswa & tgl_msk \\
\hline id_jns_keluar & character(1) & $\begin{array}{l}\text { Web Service: } \\
\text { GetRecordset:jeni } \\
\text { s_keluar }\end{array}$ & & & \\
\hline tgl_keluar & date & yyyy-mm-dd & & & \\
\hline ket & $\begin{array}{l}\text { character } \\
\text { varying }(128)\end{array}$ & Keterangan & & & \\
\hline skhun & character(20) & & & mahasiswa & noijazah \\
\hline a_pernah_paud & numeric $(1,0)$ & $\begin{array}{l}\text { 0: Tidak pernah } \\
\text { PAUD, 1: Pernah } \\
\text { PAUD }\end{array}$ & & & \\
\hline a_pernah_tk & numeric $(1,0)$ & $\begin{array}{l}\text { 0: Tidak pernah } \\
\text { TK, 1: Pernah TK }\end{array}$ & & & \\
\hline mulai_smt & $\begin{array}{l}\text { character } \\
\text { varying(5) }\end{array}$ & $\begin{array}{l}\text { ID Mulai } \\
\text { Semester. Web } \\
\text { Service: } \\
\text { GetRecordset:sem } \\
\text { ester }\end{array}$ & & mahasiswa & angkatan \\
\hline sks_diakui & numeric $(3,0)$ & & & & \\
\hline jalur_skripsi & numeric $(1,0)$ & & & krs_mhs & default \\
\hline judul_skripsi & $\begin{array}{l}\text { character } \\
\text { varying }(250)\end{array}$ & & & mahasiswa & $\begin{array}{l}\text { judul_skrip } \\
\text { si }\end{array}$ \\
\hline bln_awal_bimbingan & date & yyyy-mm-dd & & krs_mhs & $\begin{array}{l}\text { tgl_krs_bu } \\
\text { ka }\end{array}$ \\
\hline bln_akhir_bimbingan & date & yyyy-mm-dd & & krs_mhs & tgl_lulus \\
\hline sk_yudisium & $\begin{array}{l}\text { character } \\
\text { varying }(40)\end{array}$ & & & & \\
\hline tgl_sk_yudisium & date & yyyy-mm-dd & & & \\
\hline ipk & $\begin{array}{l}\text { double } \\
\text { precision }\end{array}$ & $\begin{array}{l}\text { Indeks Prestasi } \\
\text { Kumulatif }\end{array}$ & & rekapkrs & \\
\hline no_seri_ijazah & $\begin{array}{l}\text { character } \\
\text { varying }(40)\end{array}$ & & & mahasiswa & no_ijazah \\
\hline sert_prof & $\begin{array}{l}\text { character } \\
\text { varying }(40)\end{array}$ & & & & \\
\hline
\end{tabular}


TELEMATIKA

\begin{tabular}{|l|l|l|l|l|}
\hline a_pindah_mhs_asing & numeric(1,0) & & & \\
\hline nm_pt_asal & & $\begin{array}{l}\text { ID Perguruan } \\
\text { Tinggi. Web } \\
\text { Service: } \\
\text { GetRecordset:satu } \\
\text { an_pendidikan }\end{array}$ & & \\
\hline nm_prodi_asal & $\begin{array}{l}\text { character } \\
\text { varying(50) }\end{array}$ & $\begin{array}{l}\text { ID SMS (Satuan } \\
\text { Manajemen } \\
\text { Sumberdaya). } \\
\text { Web Service: } \\
\text { GetRecordset:sms }\end{array}$ & & \\
& character & & & \\
& varying(50) & & & \\
& & & & \\
\hline
\end{tabular}

2. Insert data dan pengambilan data mahasiswa dari database PDDIKTI hasil mapping. Proses selanjutnya setelah mapping database CBIS dengan DIKTI adalah proses insert data mahasiswa. Tabel mahasiswa_pt adalah tabel hasil mapping yang mempunyai kesamaan dengan database feeder dengan sebelumnya dilakukan proses insert terlebih dahulu yang merupakan modul dari web service. Penggalan program insert.php dapat dilihat pada pada listing program 4.1.berikut ini.

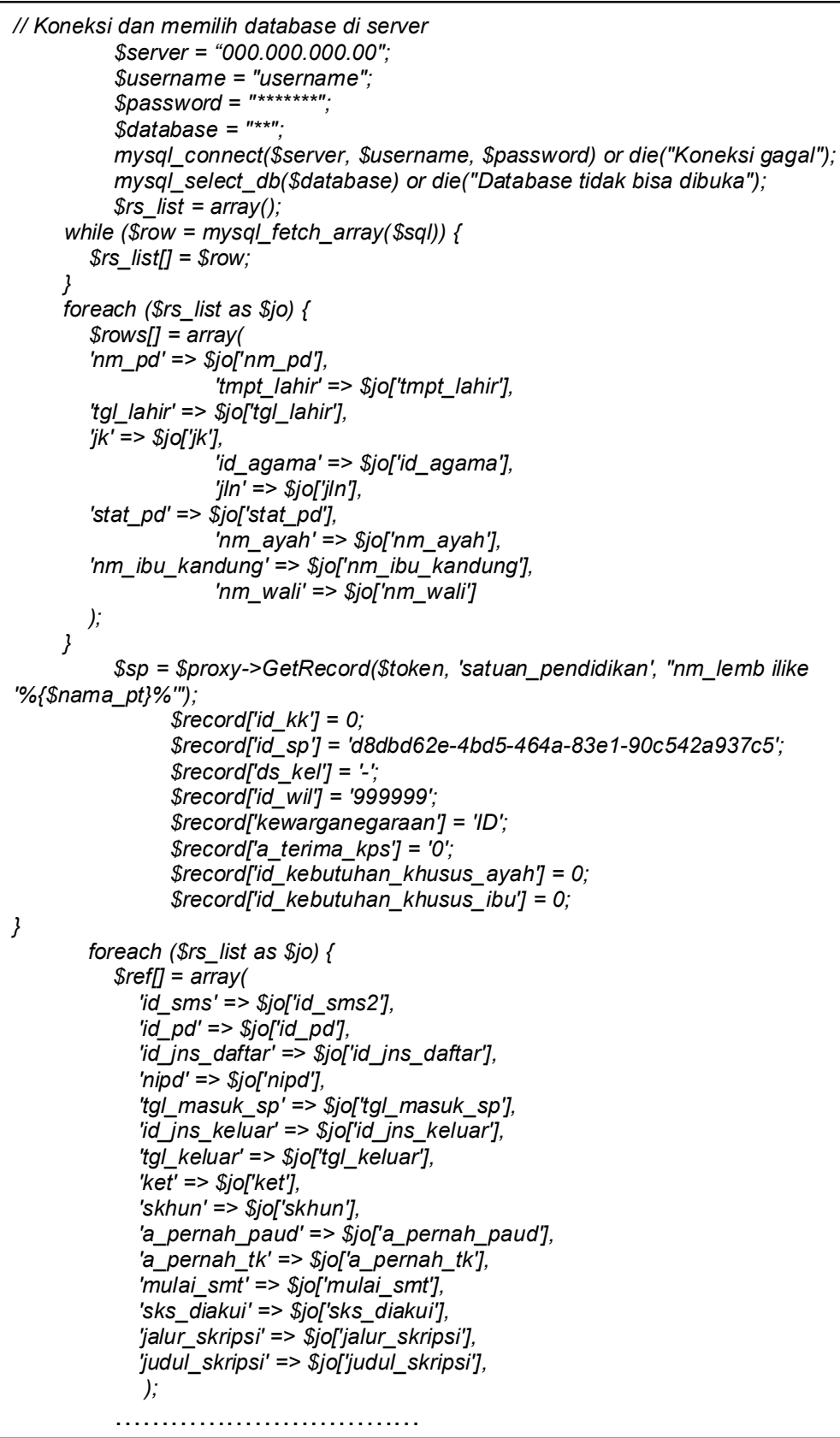




\section{Listing Program 4.1. Penggalan Kode Modul Insert.php}

Setelah proses insert data mahasiswa berhasil dilakukan, maka langkah berikutnya melihat data mahasiswa yang baru saja di inputkan pada tabel mahasiswa_pt. Dengan bantuan SQL-yog, data mahasiswa hasil mapping telah dapat di lihat dengan format yang telah sesuai dengan replika DIKTI. Gambar 4.1. berikut adalah tampilan gambar lihat data mahasiswa pada tabel mahasiswa_pt.

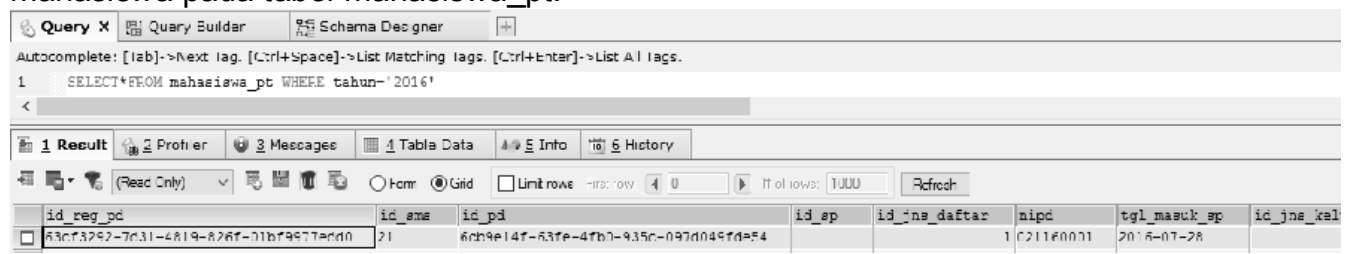

\section{Gambar 4.1. Lihat Data Mahasiswa}

3. Insert Data dari Database mapping PDDIKTI ke Aplikasi Feeder melalui web service di lokal universitas (Gambar 4.2). Langkah yang diambil adalah data dari replika data PDDIKTI (Memasukkan data mahasiswa dan mahasiswa_pt) kemudian insert melalui Web Service. Proses ini terjadi pada web service.

Insert mahasiswa

Data mahasiswa yang akan dimasukkan

\begin{tabular}{|c|c|c|c|c|c|c|c|c|c|c|c|c|c|c|}
\hline No & nm_pd & $\mathrm{Jk}$ & jIn & $\mathrm{rt}$ & $\mathrm{rw}$ & nm_dsn & kode_pos & nisn & nlk & tmpt_lahlr & tgl_lahlr & nm_ayah & tgl_lah|r_ayah & Id」Jenjang_pendld \\
\hline 1. & $\begin{array}{l}\text { ARDHIA } \\
\text { ACNFS } \\
\text { FADHAT| } \\
\text { SITARFSIMII }\end{array}$ & $P$ & $\begin{array}{l}\text { PURI } \\
\text { NIRWANA } \\
2 \text { BLCK } \\
\text { RB } \\
\text { NO. } 2^{\prime}\end{array}$ & 3 & 13 & $\begin{array}{l}\text { HARAPAN } \\
\text { IAYA }\end{array}$ & 16911 & 9973455807 & 3201016107970010 & $\begin{array}{l}\text { KAB. } \\
\text { AOCOR }\end{array}$ & 19970721 & $\begin{array}{l}\text { AGUNG } \\
\text { CIINAWAN }\end{array}$ & 19680227 & 6 \\
\hline
\end{tabular}

\begin{tabular}{|l|l|}
\hline Inset thecord & IrsertKecondset \\
\hline
\end{tabular}

\section{Gambar 4.2. Field dari tabel mahasiswa}

Menggunakan Universal Uniq Identifier (UUID) sebagai kunci utama dalam table - RFC 4122 dengan format: $X X X X X X X X-X X X X-V X X X-Z X X X-X X X X X X X X X X X X$

contoh: de305d54-75b4-431b-adb2-eb6b9e546013

Uniq Mahasiswa : Nama + Tmp/Tgl Lahir + Nama Ibu

Hasilnya dilihat pada Gambar 4.3.

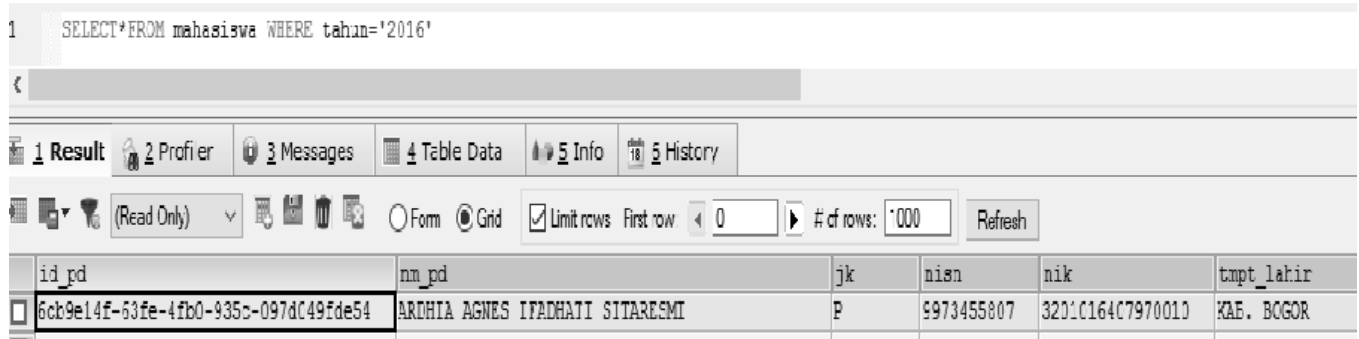

Gambar 4.3. Hasil kelengkāpan data

4. Setelah hasil insert dilakukan pada database feeder (lokal universitas) maka hasil Insert mahasiswa di aplikasi feeder sudah dapat dilihat. Gambar 4.4 dan Gambar 4.5 adalah tampilan hasil insert data mahasiswa (tabel mahasiswa) yang menjadi contoh dalam pembahasan ini. Tampilan tersebut adalah tampilan menu aplikasi feeder (lokal universitas). 


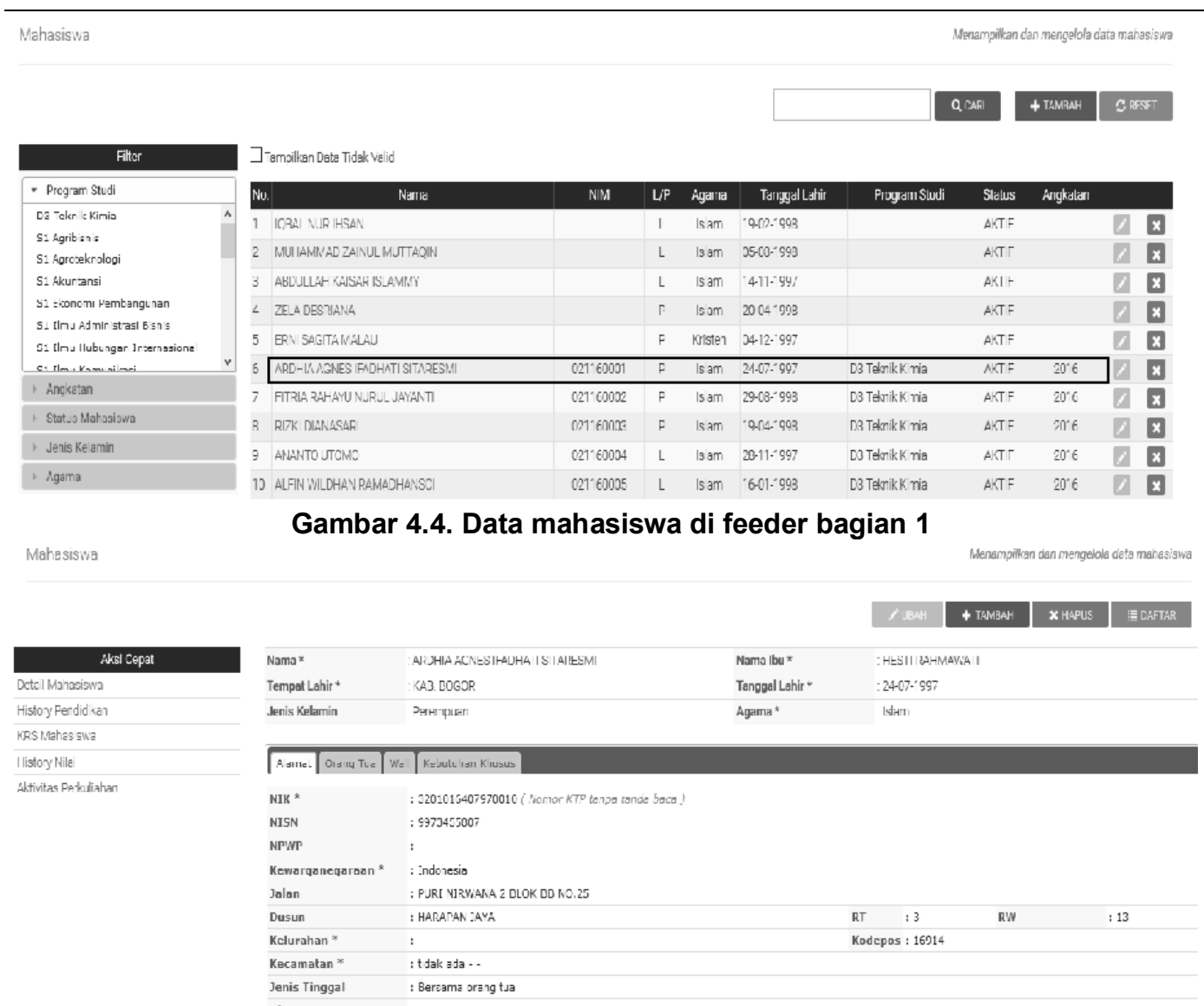

Gambar 4.5. Data mahasiswa di feeder bagian 2

5. Proses terakhir adalah sinkronisasi data feeder (lokal universitas) dengan server forlap DIKTI yang beralamatkan di http://forlap.dikti.go.id

Proses sinkronisasi ini bertujuan untuk memvalidasi sekaligus memastikan data yang ada di aplikasi feeder (lokal upn) dapat terkirim menuju aplikasi forlap.dikti (pusat).

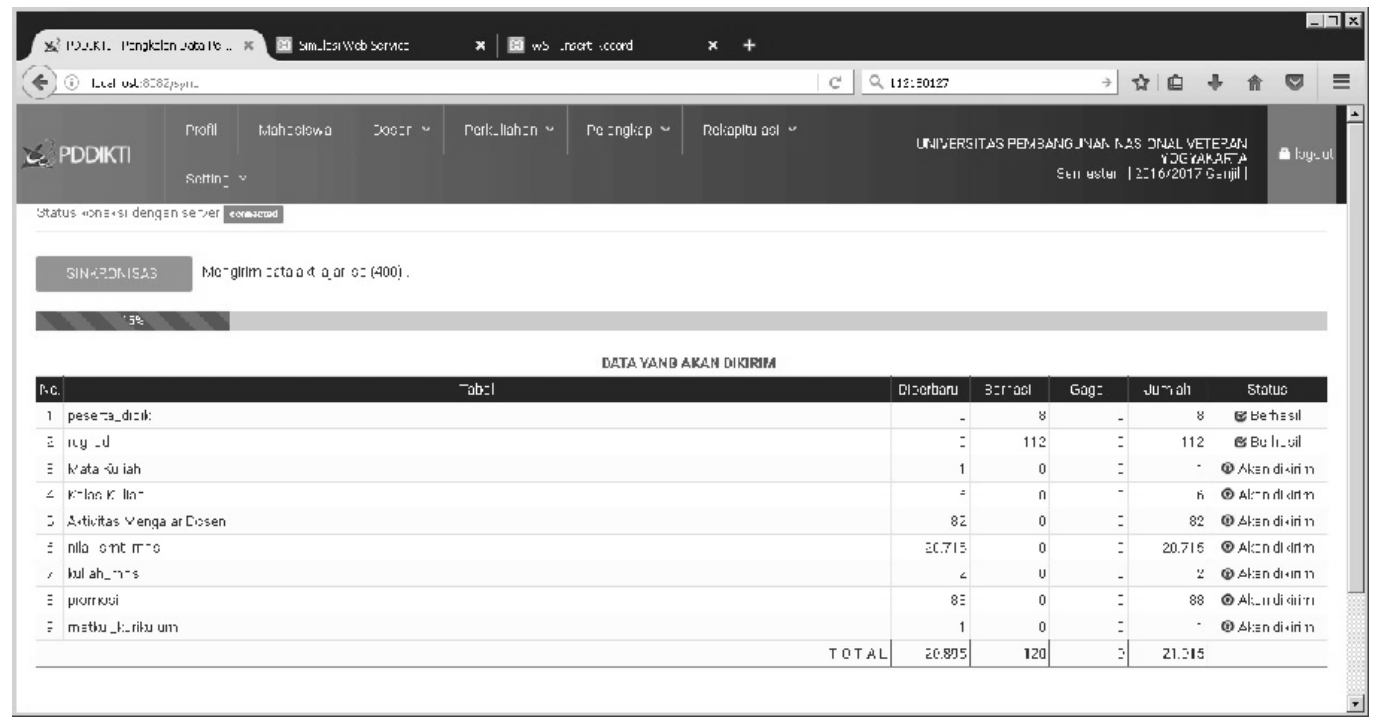

Gambar 4.6. Proses sinkronisasi data feeder dengan forlap dikti 
Hasil Sinkronisasi ke forlap dikti dapat dilihat di forlap.dikti.go.id

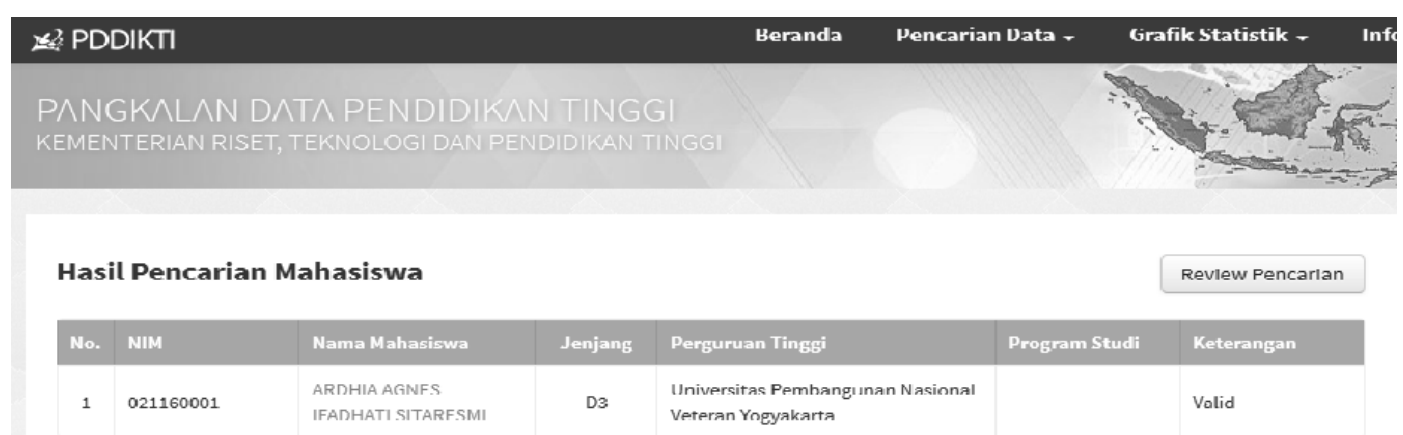

Gambar 4.7. Hasil Sinkronisasi di laman forlap.dikti

\section{KESIMPULAN}

Kesimpulan dari penelitian ini adalah

1. Proses integrasi data CBIS akademik dengan pangkalan data DIKTI telah terimplementasi dengan baik.

2. Perubahan struktur database yang dilakukan oleh DIKTI akan berdampak pada perubahan modul-modul web service disisi client.

3. Perbedaan atribut data-data CBIS akademik dengan atribut database feeder DIKTI telah teratasi dengan web service ini.

\section{DAFTAR PUSTAKA}

Chen et al., 2003, The implications and impacts of web services to e-commerce research and practices, Journal of Electronics Commerce Research, VOL 4. NO.4, 2003.

Deviana, H., 2011, Penerapan XML Web Service pada Sistem Distribusi Barang, Jurnal Generic, no. 2, vol. 6, hal. 55-62.

Hartono, F.F., Hendry, Somya,R., 2012, Aplikasi Reservasi Tiket Bus pada Handphone Android menggunakan Web service (Studi Kasus: PO. Rosalia Indah), Program Studi Teknik Informatika Fakultas Teknologi Informasi Universitas Kristen SatyaWacana Salatiga.

Hidayat, A., Ashari, A., 2013, Penerapan Web Services untuk integrasi layanan puskesmas dan rumah sakit, Jurnal Online FMIPA UGM, Berkala MIPA, (23)1, Januari 2013.

Kreger, H., 2001. Web Service Conceptual Architecture (WSCA 1.0), IBM Software Group, May 2001.

Marthasari, G.I, Aminudin, Munarko,Y., 2010, Implementasi Web service Untuk Mendukung Interoperabilitas Pada Aplikasi E-Commerce, The 12th Industrial Electronics Seminar 2010 (IES 2010) Electronics Engineering Polytechnic Institute of Surabaya (EEPIS), Indonesia, Nopember 3, 2010.

Pressman, Roger S., 2010, Software Engineering $7^{\text {th }}$ A Practitioner Approach, McGraw-Hill.

Santosa, B. \& Perwira, R.I., 2016, Pengembangan Integrasi Data CBIS Akademik Dengan Replika Pangkalan Data DIKTI UPN "Veteran" Yogakarta Menggunakan Web Service. Prosiding LPPM UPN Tahun 2016, ISBN 978-602-60245-0-3

Sutanta, E., Mustofa, K., 2012, Strategi pengembangan web services untuk integrasi inter sistem e-gov di pemerintahan kabupaten bantul, Jurnal ilmiah SISFOTENIKA, Juli, 2012.

Short, Scott. 2003. Building XML Web Services For The Microsoft .Net Platform. Jakarta : PT Elex Media Komputindo.

Utama, Y., 2010. Teknik Pemrograman Web Service PHP Dengan Menggunakan SOA dan WSDL, Teknik Informatika, Universitas Atma Jaya Yogyakarta

Yazdi, M., 2012, Implementasi web services pada sistem pelayanan perijinan terpadu satu atap di pemerintahan kota palu, Seminar Nasional Teknologi Informasi \& Komunikasi Terapan 2012 (Semantik 2012), ISBN 979-26-0255-0, Juni, 2012. 